\title{
Inflation and the Indian Economy
}

\author{
Naresh kanwar, \\ Research Scholar Barkutallah University ,Bhopal
}

\begin{abstract}
Inflation is as common in Indian economy as cold and flu in winter season. It is therefore one of the biggest challenge for an economy like India which is on the path of growth and development, inflation is like a caterpillar that eats away the growing cream of an economy. In this research paper we are going to analysis the inflation and its factors, the challenges that it brings and will also summarize the inflation since independence, particularly the food inflation and examine the demand and supply side factors behind surging food prices. It will further explain the methods of measuring the inflation, the different types of inflation and what factors are responsible for the current high rate of inflation in India.
\end{abstract}

\section{Introduction}

Inflation is a rise in the general level of prices of goods and services in an economy over a period of time. When the general price level rises, each unit of currency buys fewer goods and services .Consequently, inflation reflects a reduction in the purchasing power per unit of money a loss of real value in the medium of exchange and unit of account within the economy.

Inflation is defined as a sustained increase in the general level of prices for goods and services .It is measured as an annual percentage increase.

The rate at which the general level of prices for goods and services is rising and subsequently , purchasing power is falling. Central banks attempt to stop severe inflation along with severe deflation in an attempt to keep the excessive growth of price to a minimum

Another way of looking at inflation is "too much money chasing too few goods". The last definition attributes the cause of inflation to monetary growth rate to the output / availability of goods and services in the economy. If the prices of only one commodity rise sharply but prices of other commodities fall it will not be termed as inflation, similarly due to rumours if the price of a commodity rises during the day itself, it will not be termed as inflation.

\section{Types of Inflation}

Inflation is divided in two categories

1) Demand Pull inflation : In this type of inflation prices increase results from an excess of demand over supply for the economy as a whole demand inflation occurs when the supply cannot expand any more to meet demand that is when critical production factors are being fully utilized also called demand inflation.

2) Cost push inflation: This type of inflation occurs when general price level rise owing to rising input costs .In general these factors that contribute to cost push inflation rising wages increase in corporate taxes and imported inflation.(Imported raw or partly finished goods may become expensive due to rise in international costs or as a result of depreciation of local currency.)

3) Negative effect of inflation : Negative effect of inflation include an increase in the opportunity cost of the holding money, uncertainty over future inflation which may discourage investment and savings and if inflation is rapid enough ,shortage of goods as consumers begin hoarding out of concern that prices will increase in the future

4) Positive effect of inflation: Positive effect includes ensuring that central banks can adjust real interest rates and encouraging investment in non monetary capital projects.

Most economists favour a low and steady rate of inflation as opposed to zero or negative inflation reduces the severity of economic recessions by enabling the labour market to adjust to more quickly in a downturn and reduces the risk that a liquidity trap prevents monetary policy from stabilizing the economy. The task of keeping the rate of inflation low and stable is usually given to monetary authorities.

\section{History of inflation in India}

Inflation is a permanent characteristic of Indian economy. After the second world war there has been a strong inflationary pressure on the economy, because of the high demand and low supply because of the rapid growing of Indian population, rising money incomes, expansion in money supply and liquidity in the country, using volume of black money and continuous rise in demand for goods and services due to rapid economic development. 


\section{Post war inflation in India}

The post war period saw the political crisis, partion of the country, social up heals and huge massacres, there was an inflationary trend which has remained repressed during this period.

From (1949-69)

This phase marks the nationalization of 14 commercial banks. This period inherited a strong inflationary pressure because of the world wars and the devaluation of Indian rupee.

The situation or the inflation was further aggregated by the Korean War in the year 1950-51 but was stabilized in the coming years because of the bumper agriculture production in the country thus the period experienced a moderate inflation rate during the period.

From (1969-1991)

This was the period of inflation and economy landing into the balance of payment crisis and forced to adopt for reaching economic reforms covering various sectors of the economy .The four years period ie 1971$72,74-75$ was the period of hyper inflation in the country with inflation rate touching at $15.25 \%$ but government measures brought back the high inflation on track but again in the year 1970 inflation was $9 \%$ due to poor agriculture output and crude oil prices .The decade 1980 also experienced the period of inflation compared to the last decade more or less it was approx. $7.5 \%$., but the next decade moved a step further in this direction and rate of inflation in 1990-91was $10 \%$.

From (1991-2009)

Liberalization of the imports, adoption of the flexible exchange rate system, convertibility of the rupee deregulation of the interest rate, deservation of the public sector, abolition of the industrial licensing and the restrictive provision of the MRTP Act, reduction in fiscal and revenues deficit etc were some of the important reforms introduced since 1990and they have changed the entire Indian economy.

Because of the various measures taken during the period, in the initial years the inflation rate was $10 \%$. The second half of the 1990s saw a significant outcome the average inflation rate during this period declined from $10 \%$ in the first half to $5.08 \%$.

The factors responsible for this were

1) RBI policy

2) Cooling of global inflation

3) Depreciation of rupee slowed down

4) Large buffer of food grains

Inflation after 2009

Inflation rate in India is reported by the ministry of commerce and industry of India. The wholesale price index (WPI) is the main measure of inflation. The WPI measures the price of a representative basket of wholesale goods.

These wholesale price index is divided into three groups.

1) Primary index : $20 \%$ of total weight

2) Fuel and power : $49 \%$

3) Manufactured products : $65 \%$

4) Food articles : $14.3 \%$

5) Metals and alloys : $10.8 \%$

6) Machinery and tools : $8.9 \%$

7) Textiles :7.3\%

8) Transport, equipment \& parts : $5.2 \%$

The Consumer Price Index (CPI) is a statistical estimate constructed using the prices of a sample of representative items whose prices are collected periodically. Sub-indexes and sub-sub-indexes are computed for different categories and sub-categories of goods and services, being combined to produce the overall index with weights reflecting their shares in the total of the consumer expenditures covered by the index. It is one of several price indices calculated by most national statistical agencies. The annual percentage change in a CPI is used as a measure of inflation. A CPI can be used to index (i.e., adjust for the effect of inflation) the real value of wages, salaries, pensions for regulating prices and for deflating monetary magnitudes to show changes in real values. 


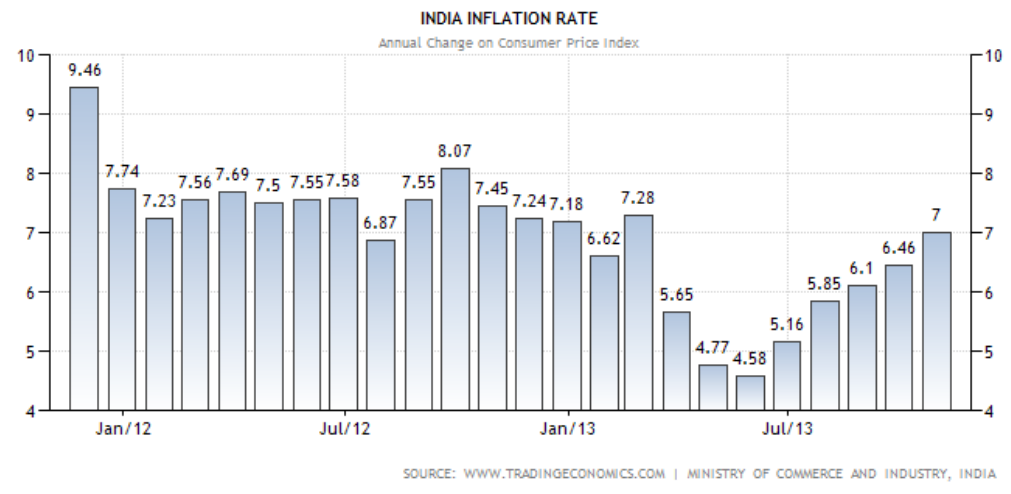

Consumer Price Index (CPI) in India increased to 238 Index Points in September of 2013 from 237 Index Points in August of 2013. Consumer Price Index (CPI) in India is reported by the Labour Bureau, Government of India. Consumer Price Index (CPI) in India averaged 56.67 Index Points from 1960 until 2013, reaching an all time high of 238 Index Points in September of 2013 and a record low of 4.32 Index Points in March of 1960. In India, the Consumer Price Index or CPI measures changes in the prices paid by consumers for a basket of goods and services. This page contains - India Consumer Price Index (CPI) - actual values, historical data, forecast, chart, statistics, economic calendar and news. 2013

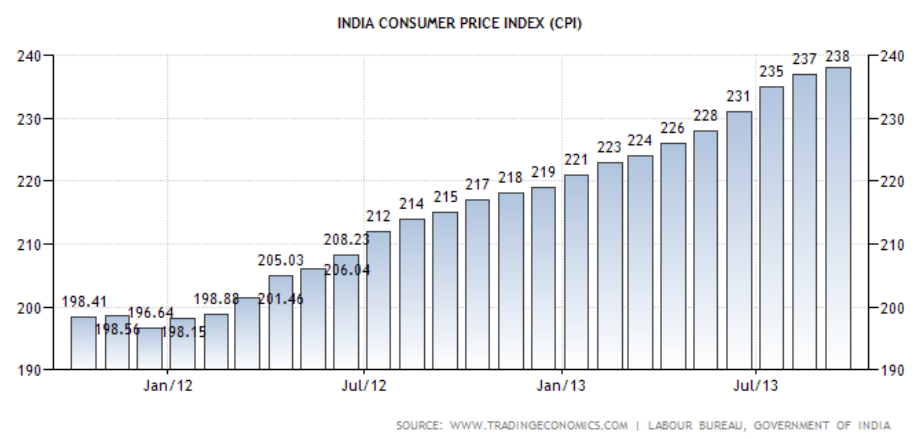

Provisional all India annual inflation rates (\%) for October 2013.

\begin{tabular}{|c|c|c|c|c|c|c|c|c|c|c|}
\hline & \multirow[t]{2}{*}{ Category } & \multicolumn{3}{|l|}{ Rural } & \multicolumn{3}{|l|}{ Urban } & \multicolumn{3}{|c|}{ Combined } \\
\hline & & $\begin{array}{l}\text { Oct.12 } \\
\text { Index } \\
\text { Final }\end{array}$ & $\begin{array}{l}\text { Oct.13 } \\
\text { Index } \\
\text { Prov. }\end{array}$ & $\begin{array}{l}\text { Rate } \\
(\%)\end{array}$ & $\begin{array}{l}\text { Oct.12 } \\
\text { Index } \\
\text { Final } \\
\end{array}$ & $\begin{array}{l}\text { Oct.13 } \\
\text { Index } \\
\text { Prov. }\end{array}$ & $\begin{array}{l}\text { Rate } \\
(\%)\end{array}$ & $\begin{array}{l}\text { Oct.12 } \\
\text { Index } \\
\text { Final }\end{array}$ & $\begin{array}{l}\text { Oct.13 } \\
\text { Index } \\
\text { Prov. }\end{array}$ & $\begin{array}{l}\text { Rate } \\
(\%)\end{array}$ \\
\hline 1 & Cereals and products & 119.9 & 133.9 & 11.68 & 117.0 & 132.0 & 12.82 & 119.1 & 133.4 & 12.01 \\
\hline 2 & Pulses and products & 115.1 & 118.5 & 2.95 & 119.6 & 114.4 & -4.35 & 116.5 & 117.2 & 0.60 \\
\hline 3 & Oils and fats & 141.0 & 143.9 & 2.06 & 146.5 & 141.9 & -3.14 & 142.8 & 143.3 & 0.35 \\
\hline 4 & Egg, fish and meat & 130.3 & 144.3 & 10.74 & 129.0 & 146.9 & 13.88 & 129.9 & 145.2 & 11.78 \\
\hline 5 & Milk and products & 134.4 & 144.8 & 7.74 & 128.9 & 139.0 & 7.84 & 132.4 & 142.7 & 7.78 \\
\hline 6 & Condiments and spices & 128.1 & 135.1 & 5.46 & 122.4 & 132.9 & 8.58 & 126.4 & 134.5 & 6.41 \\
\hline 7 & Vegetables & 137.6 & 194.1 & 41.06 & 122.8 & 192.5 & 56.76 & 132.9 & 193.6 & 45.67 \\
\hline 8 & Fruits & 136.9 & 157.8 & 15.27 & 130.1 & 142.4 & 9.45 & 134.0 & 151.2 & 12.84 \\
\hline 9 & Sugar etc & 114.5 & 110.3 & -3.67 & 117.2 & 105.7 & -9.81 & 115.3 & 109.0 & -5.46 \\
\hline 10 & Non-alcoholic beverages & 126.2 & 135.9 & 7.69 & 124.6 & 137.2 & 10.11 & 125.5 & 136.5 & 8.76 \\
\hline 11 & Prepared meals etc & 125.3 & 135.9 & 8.46 & 125.8 & 138.3 & 9.94 & 125.5 & 137.1 & 9.24 \\
\hline 12 & $\begin{array}{l}\text { Food and beverages (1 to } \\
\text { 11) }\end{array}$ & 127.4 & 143.1 & 12.32 & 125.2 & 141.3 & 12.86 & 126.6 & 142.5 & 12.56 \\
\hline 13 & Fuel and light & 129.1 & 138.0 & 6.89 & 125.3 & 134.4 & 7.26 & 127.7 & 136.6 & 6.97 \\
\hline 14 & $\begin{array}{l}\text { Clothing, bedding and } \\
\text { footwear }\end{array}$ & 132.8 & 145.1 & 9.26 & 133.2 & 145.1 & 8.93 & 132.9 & 145.1 & 9.18 \\
\hline & $\begin{array}{l}\text { General Index } \\
\text { Groups) }\end{array}$ & 126.6 & 139.4 & 10.11 & 122.6 & 135.1 & 10.20 & 124.9 & 137.5 & $10.09 *$ \\
\hline
\end{tabular}

Source: provisional central statistics office

Another way of measuring inflation is wholesale price index.

The Wholesale price index (WPI) is the price of a representative basket of wholesale goods .India use WPI changes as a central measure of inflation. The Indian WPI figure was earlier released weekly on every Thursday and influenced stock and fixed price markets. The Indian WPI is now updated on a monthly basis. The Wholesale Price Index focuses on the price of goods traded between corporations, rather than goods bought by 
consumers, which is measured by the consumer price index The purpose of the WPI is to monitor price movements that reflect supply and demand in industry, manufacturing and construction. This helps in analyzing both macroeconomic and microeconomic conditions. Inflation is based on Wholesale Price Index.

How WPI is Calculated

The wholesale price index (WPI) is based on the wholesale price of a few relevant commodities of over 240 commodities available. The commodities chosen for the calculation are based on their importance in the region and the point of time the WPI is employed. For example in India about 435 items were used for calculating the WPI in base year 1993-94 while the advanced base year 2004-05 and which has now been changed to 2010-2011; uses 676 items. The indicator tracks the price movement of each commodity individually. Based on this individual movement, the WPI is determined through the averaging principle.

Wholesale Price Inflation (Average) - 1953-54 to 2011-12 (upto March 2012) (Per cent)

\begin{tabular}{|c|c|c|c|c|c|c|}
\hline \multirow[t]{2}{*}{ Year } & \multirow[t]{2}{*}{ All Commodity } & \multirow{2}{*}{$\begin{array}{l}\text { Primary } \\
\text { Articles }\end{array}$} & \multicolumn{2}{|l|}{ of which } & \multirow{2}{*}{$\begin{array}{l}\text { Fuel, Power, } \\
\text { Light and } \\
\text { Lubricants }\end{array}$} & \multirow{2}{*}{$\begin{array}{l}\text { Manufactured } \\
\text { Products }\end{array}$} \\
\hline & & & Food Articles & Non-food Articles & & \\
\hline 1 & 2 & 3 & 4 & 5 & 6 & 7 \\
\hline \multicolumn{7}{|c|}{$($ Base $:$ 1952-53 = 100) } \\
\hline $1953-54$ & 4.6 & . & 6.7 & . & -0.8 & -1.0 \\
\hline $1954-55$ & -6.8 & . & -11.3 & . & -2.1 & 1.6 \\
\hline $1955-56$ & -5.2 & . & -8.5 & . & -2.0 & -0.9 \\
\hline $1956-57$ & 14.0 & . & 18.1 & . & 9.5 & 6.6 \\
\hline $1957-58$ & 2.9 & . & 4.1 & . & 8.8 & 1.7 \\
\hline $1958-59$ & 4.1 & . & 8.2 & . & 1.8 & 0.3 \\
\hline $1959-60$ & 3.8 & . & 3.3 & . & 1.0 & 3.0 \\
\hline $1960-61$ & 6.6 & . & 0.8 & . & 3.0 & 10.9 \\
\hline 1961-62 & 0.2 & . & 0.1 & -1 & 1.7 & 2.2 \\
\hline \multicolumn{7}{|c|}{ (Base : $1961-62=100)$} \\
\hline $1962-63$ & 3.8 & . & 6.5 & . & 3.2 & 3.1 \\
\hline $1963-64$ & 6.2 & . & 8.4 & . & 14.4 & 2.5 \\
\hline $1964-65$ & 11.0 & . & 17.3 & . & 1.9 & 3.9 \\
\hline 1965-66 & 7.6 & . & 6.8 & . & 3.2 & 7.7 \\
\hline $1966-67$ & 13.9 & . & 18.3 & . & 8.4 & 8.0 \\
\hline $1967-68$ & 11.6 & . & 21.4 & . & 5.6 & 3.2 \\
\hline 1968-69 & -1.1 & . & -5.2 & . & 4.6 & 2.3 \\
\hline $1969-70$ & 3.7 & . & -0.1 & . & 4.4 & 6.0 \\
\hline $1970-71$ & 5.5 & . & 3.6 & . & 4.3 & 7.9 \\
\hline \multicolumn{7}{|c|}{ (Base : $1970-71=100)$} \\
\hline $1971-72$ & 5.6 & 0.9 & 1.1 & -1.4 & 5.9 & 9.5 \\
\hline $1972-73$ & 10.0 & 9.7 & 10.1 & 9.0 & 4.0 & 11.3 \\
\hline 1973-74 & 20.2 & 28.1 & 22.7 & 36.4 & 18.6 & 14.4 \\
\hline $1974-75$ & 25.2 & 25.2 & 26.0 & 11.7 & 51.8 & 21.0 \\
\hline $1975-76$ & -1.1 & -6.6 & -4.9 & -14.6 & 10.5 & 1.4 \\
\hline 1976-77 & 2.1 & 0.8 & -5.1 & 19.7 & 5.3 & 2.3 \\
\hline $1977-78$ & 5.2 & 9.9 & 11.8 & 6.3 & 1.5 & 2.3 \\
\hline 1978-79 & 0.0 & -1.3 & -0.7 & -4.3 & 4.4 & 0.2 \\
\hline $1979-80$ & 17.1 & 13.8 & 8.2 & 14.2 & 15.7 & 20.2 \\
\hline $1980-81$ & 18.2 & 15.0 & 11.4 & 11.9 & 25.2 & 19.2 \\
\hline $1981-82$ & 9.3 & 11.3 & 13.1 & 10.5 & 20.7 & 5.2 \\
\hline \multicolumn{7}{|c|}{ (Base : 1981-82 = 100) } \\
\hline $1982-83$ & 4.9 & 6.7 & 11.1 & 0.8 & 6.5 & 3.5 \\
\hline $1983-84$ & 7.5 & 10.8 & 13.9 & 11.5 & 5.6 & 6.1 \\
\hline $1984-85$ & 6.5 & 6.2 & 4.2 & 10.9 & 4.3 & 7.0 \\
\hline $1985-86$ & 4.4 & 0.2 & 1.7 & -3.4 & 10.7 & 6.0 \\
\hline 1986-87 & 5.8 & 9.1 & 10.2 & 11.4 & 6.8 & 3.8 \\
\hline $1987-88$ & 8.1 & 11.3 & 9.0 & 21.6 & 3.4 & 7.2 \\
\hline 1988-89 & 7.5 & 4.9 & 9.9 & -1.7 & 5.5 & 9.4 \\
\hline 1989-90 & 7.5 & 2.2 & 1.2 & 3.6 & 3.6 & 11.3 \\
\hline 1990-91 & 10.3 & 13.0 & 11.9 & 17.0 & 12.3 & 8.4 \\
\hline 1991-92 & 13.7 & 18.1 & 20.2 & 18.0 & 13.2 & 11.3 \\
\hline $1992-93$ & 10.1 & 7.5 & 12.4 & -0.2 & 14.1 & 10.9 \\
\hline $1993-94$ & 8.4 & 6.9 & 4.9 & 8.9 & 15.5 & 7.8 \\
\hline \multicolumn{7}{|c|}{ (Base : 1993-94 = 100) } \\
\hline $1994-95$ & 12.6 & 15.8 & 12.8 & 24.2 & 8.9 & 12.3 \\
\hline $1995-96$ & 8.0 & 8.2 & 8.3 & 9.0 & 5.1 & 8.5 \\
\hline 1996-97 & 4.6 & 8.4 & 12.4 & -0.9 & 10.4 & 2.1 \\
\hline
\end{tabular}


Inflation And The Indian Economy

\begin{tabular}{|c|c|c|c|c|c|c|}
\hline $1997-98$ & 4.4 & 2.7 & 3.0 & 2.5 & 13.8 & 2.9 \\
\hline $1998-99$ & 5.9 & 12.1 & 12.7 & 10.4 & 3.3 & 4.4 \\
\hline 1999-00 & 3.3 & 1.2 & 3.8 & -5.8 & 9.1 & 2.7 \\
\hline $2000-01$ & 7.2 & 2.8 & 3.0 & 2.4 & 28.5 & 3.3 \\
\hline $2002-03$ & 3.4 & 3.3 & 1.8 & 8.2 & 5.5 & 2.6 \\
\hline 2003-04 & 5.5 & 4.3 & 1.3 & 12.6 & 6.4 & 5.7 \\
\hline 2004-05 & 6.5 & 3.6 & 2.6 & 0.7 & 10.1 & 6.3 \\
\hline $2005-06$ & 4.4 & 4.3 & 5.4 & -3.3 & 13.5 & 2.4 \\
\hline 2006-07 & 6.6 & 9.6 & 9.6 & 5.8 & 6.5 & 5.7 \\
\hline 2007-08 & 4.7 & 8.3 & 7.0 & 11.9 & 0.0 & 4.8 \\
\hline 2008-09 & 8.1 & 11.0 & 9.1 & 12.9 & 11.6 & 6.2 \\
\hline $2009-10$ & 3.8 & 12.7 & 15.3 & 5.5 & -2.1 & 2.2 \\
\hline
\end{tabular}

Note : 1. Major groups/sub-groups under the various series are not strictly comparable on account of changes in classification of commodities over time. 2. In the series (Base: 1961-62=100), MP comprises sub-groups chemicals, machinery and transport equipment and manufactures. 3. Also see Notes on Tables. Source: (i) RBI, Handbook of Statistics on Indian Economy 2011- 2012 - http://rbidocs.rbi.org.in/rdocs/publication/PDFS/232 (ii) RBI, Handbook of Monetary Statistics of India 2006 - http://rbidocs.rbi.org.in/rdocs/publication/PDFS/690

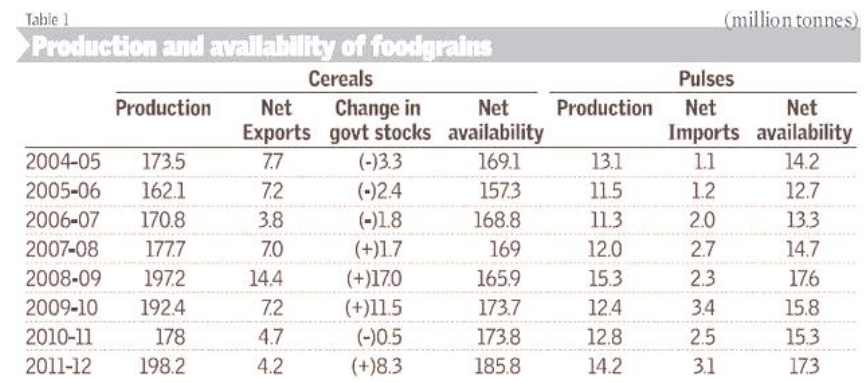

Source by: Chandraserhar \& Jayanti Ghoshfrom the hindubusinessline.

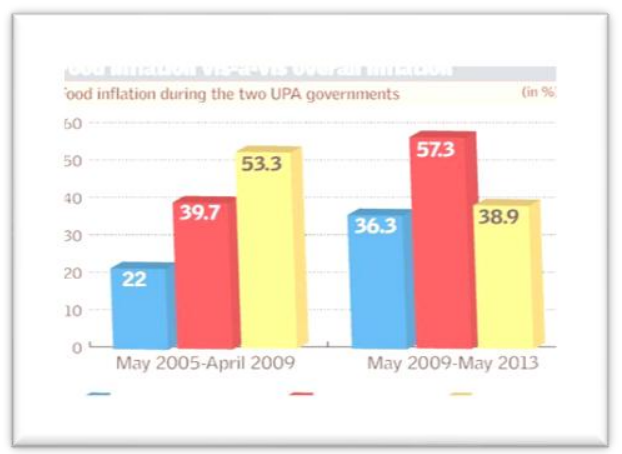

Source by: Chandraserhar \& Jayanti Ghosh from the hindubusinessline.

Factors responsible for price hike are.

In general, the following factors are attributed to rise in prices

1. Area and production, which is dependent in weather and technology.

2. Demand and consumption

3. Minimum support price

4. Government policies

5. Substitute product

6. Seasonal cycle

7. International prices

8. Natural disaster

9. War

10. Decrease in natural commodities 


\section{Demand and consumption}

When people are more confident about their financial future, they tend to spend more, contributing to a rise in prices. A dip in currency exchange rates can lead to an increase in the value of imported goods, while causing a reduction in the value of exports. When this happens, prices in the local market will go up as importers and

manufacturers transfer the cost to local consumers, causing the price of goods to increase.

Area and production, which is dependent on weather and technology

Weather and technology also effect the price of a commodity in a country like India, where large part of the agriculture produce is still dependent on weather conditions i.e. if rainfall is adequate and insecticides and pesticides are used at proper stage then the country will experience bumper agriculture produce, a bumper agriculture produce will aromatically reduce the price thus will help in fighting with inflation and will help in the growth of the economy.

\section{Minimum support price}

This is the price at which government purchase crops from the farmers . The minimum support price were announced by the government of India for the first time in 1966-67 for wheat in the wake of the green revolution, since then MSP has been extended to many crops at present government announces MSP for 25 crops an increase in the price of MSP also lead to inflation in the country.

\section{Government policies:}

If we examine the figures of last five years we will find that the government has failed to augment supply of goods to match increased demand .Reserve Bank of India is held accountable for liquidity expansion in the economy which results in higher growth of nominal income than real income. Besides, there cannot be a one-to-one correspondence between money supply and inflation, when the increase in money lies outside the RBI's control, or when money becomes an endogenous rather than exogenous variable.

In other words, when producers and distributors use their price-fixing power to create a cost-push inflation spiral on the pretext of increases in input cost, industry and business demand more credit for working capital, thus leading to an increase in the quantity of money. This increase in money supply in the current period exceeds the quantity of available goods produced in the preceding period. This endogenously excess supply of money generates inflation (as against the above observation by Basil J Moore). This is what happened in India during 2009-10 to 2011-12.

\section{Substitute products:}

Different goods that, at least partly, satisfy the same needs of the consumers and therefore can be used to replace one another are called substitute products. Price of such goods shows positive cross elasticity of demand. For example consumers may buy oranges as compared to apples because the prices of oranges is less, critics would argue that substitutions in purchasing behaviour is actual evidence of inflation as

Buyers move to similar goods that are now relatively cheaper when faced with the higher prices of previous spending patterns.

\section{Seasonal cycles:}

Seasonality would refer to change in time series data for a particular activity in trade for less than a year which is regular and repetitively fluctuating. A number of aspects to this seasonality include factors that are determining. Few of these important factors are - climate, customs and traditions, month of the year and the week effect. Climate affects the production when raw materials are abundant and other months when these are weak in supply. Customs affect the sale and purchases of commodities that are held sacred like sandalwood, gold, silver etc. The recent change in the seasonal cycle is the onion prices, onion prices were on the peak and were part of this cycle which has led to the inflation in India.

\section{International Prices:}

The main cause of increase or decrease or in other words, change in the level of prices at international level is through trade, the relative price of a country's imports and exports effect people in their respective roles both as producers of internationally traded goods and services and as a consumer of item made by the global economy. Since all prices including labor costs in such an international market sence are relative than absolute, what is important is how far a given wage in a particular domestic currency provides enough to live in.

There is a direct relationship between oil prices and inflation in an economy like India ,as oil prices move up or down, inflation follows in the same direction, the reason for this hike is simple as it is used in all critical activities such as fuelling, transportation and heating homes. 


\section{Natural disaster}

India has experienced natural calamities such as earthquakes, a tsunami, floods and drought in the past few years. The extent and severity of these natural disasters determine their impact on the Indian economy. For example, as a result of drought conditions in the country during fiscal 2003, the agricultural sector recorded a negative growth of 5.2\%. Further prolonged spells of below normal rainfall, recent uttrakhand flood disaster has shattered the tourism industry of the state in general and has effect the economy at large the same thing was noticed in the recent tsunami of the state of Orissa.

\section{War}

The most consistent short-term economic effect of war is to push up prices, and consequently to reduce living standards, Wars are expensive (in money and other resources), destructive (of capital and human capital), and disruptive (of trade, resource availability, labor management). Large wars constitute severe shocks to the economies of participating countries. Notwithstanding some positive aspects of short-term stimulation and longterm destruction and rebuilding, war generally impedes economic development and undermines prosperity. Several specific economic effects of war recur across historical eras and locales. Present-day wars continue to fuel inflation and drive currencies towards worthlessness. In Angola's civil war (1975-2002), for example, the government currency became so useless that an alternative "hard" currency - bottles of beer - came to replace it in many daily transactions..

\section{Conclusion}

Inflation in general and food price inflation in particular has been a persistent problem in India over the past few years .Price stability is crucial for sustainable growth structure and factors influencing food inflation, therefore it is critical for any rational policy decision to contain it within comfortable limits.

It is essential that economic policies should be backed up with statistical information and an understanding of economic theory. Collective action from the world wide should be taken on inflation .making economic policies on this is just not easy but international coordination is important not just for achieving strong ,sustainable and balanced growth but for maintaining enough liquidity in the economy.

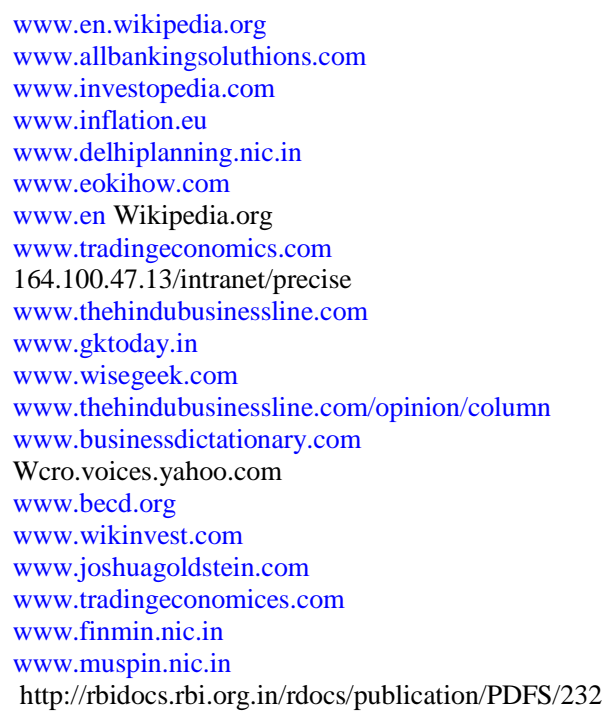

\section{References:}

